\title{
ON THE LANDING
}





\title{
ON THE LANDING
}

\author{
S T O R I E S \\ B Y \\ Y E N TA M A H
}

Tra N S L A T E D B Y E L L E N C A S S E D Y

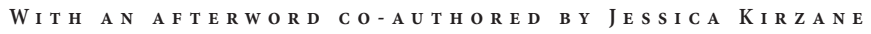

A YIDDISH BOOK CENTER TRANSLATION

N I U Press / D e Kalb I L 
Northern Illinois University Press, DeKalb 60115

(C) 2018 by Ellen Cassedy

All rights reserved

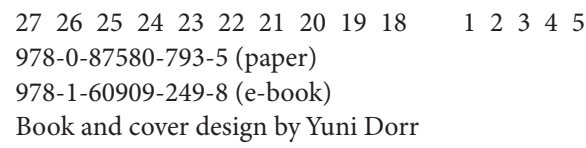

This is a work of fiction. All characters are products of the author's imagination, and any resemblance to persons living or dead is entirely coincidental.

The stories “The Bridegroom Tree," "Resting Place," "Bread," "Alone," “The Payback," and "On the Landing" were originally published in Yiddish in Tif in der tayge [Deep in the Taiga] (Tel Aviv: Farlag Yisroel Bukh, 1990), and have been translated with the kind permission of Regina Novak.

The stories "Mona Bubbe," “The Irony of Fate," “The Cap," "Ingathering of Exiles," and "Retirees" were originally published in Yiddish in Meshane mokem [A Change of Place] (Te1 Aviv: Farlag I. L. Peretz, 1993), and have been translated with the kind permission of Regina Novak.

The stories "By the Light of the Moon" and "The Second Time Around" were originally published in Yiddish in Besaraber motivn [Bessarabian Themes] (Tel Aviv: Farlag I. L. Peretz, 1998), and have been translated with the kind permission of Regina Novak.

The stories "A Seder in the Taiga," "At the Western Wall," and "Erika” were originally published in Yiddish in Mit der letster hakofe [The Last Time Around] (Tel Aviv: H. Leyvik Farlag, 2007), and have been translated with the kind permission of H. Leyvik Publishing House.

The following stories appeared previously in English translation by Ellen Cassedy: "Resting Place" in B O D Y, December 2016; "The Payback" in PEN America, July 2016; "A Seder in the Taiga" in Pakn Treger, Spring 2017; "On the Landing" in Pakn Treger, Spring 2016; "By the Light of the Moon" in Tiferet, Autumn 2017; "Mona Bubbe" in Have I Got a Story for You: More Than a Century of Fiction from the Forward, Ezra Glinter, ed. (New York: W. W. Norton \& Company, 2016); "Ingathering of Exiles" in Words Without Borders, Fall 2016; "The Second Time Around" in JewishFiction.net, no. 19, September 2017.

Library of Congress Cataloging-in-Publication Data is available online at http://catalog.loc.gov 